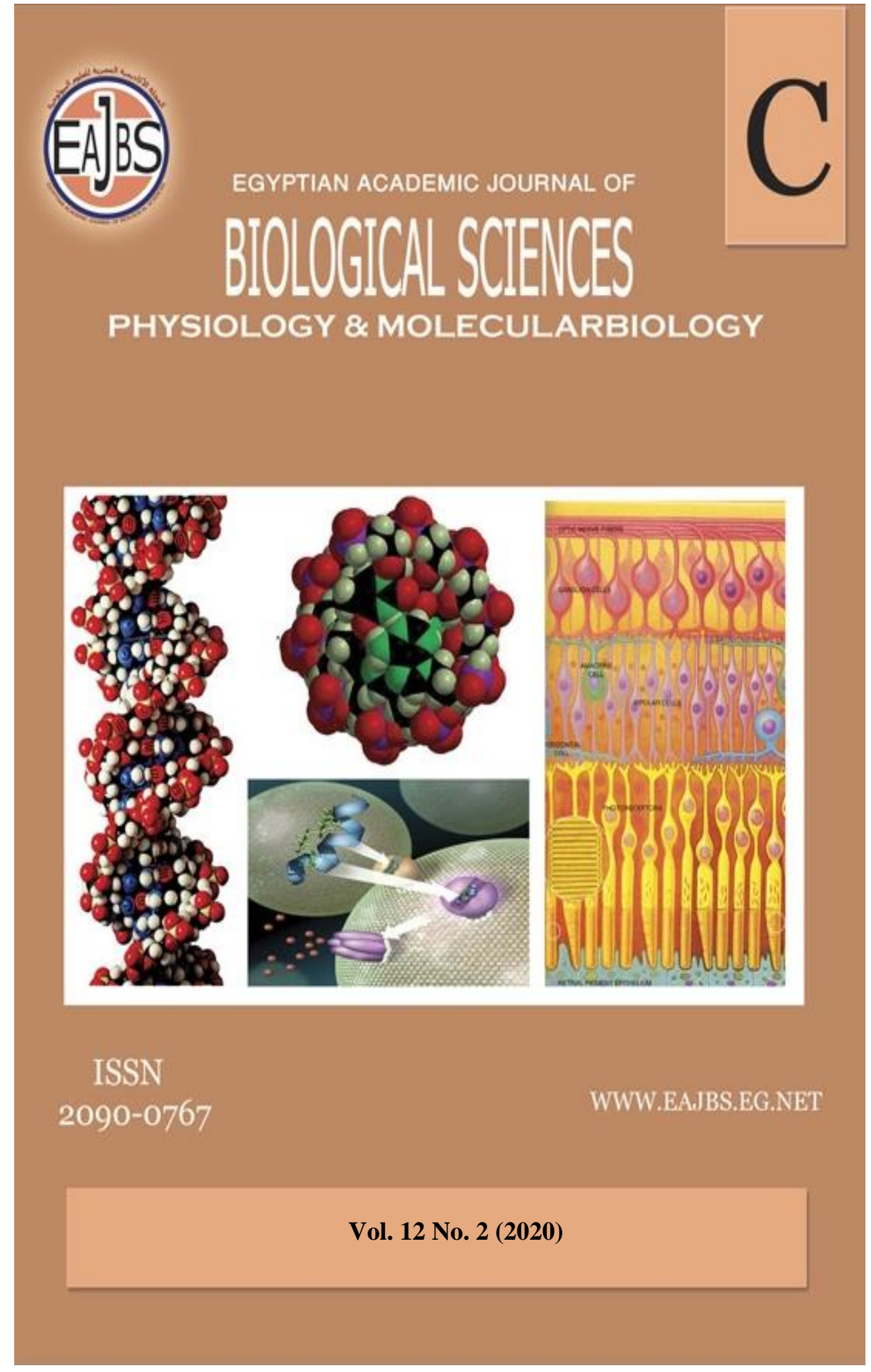


Egypt. Acad. J. Biolog. Sci., 12(2):241-248 (2020)

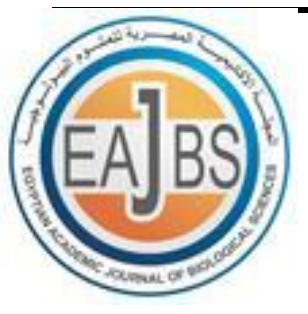

Egyptian Academic Journal of Biological Sciences

C. Physiology \& Molecular Biology

ISSN 2090-0767

www.eajbsc.journals.ekb.eg

\title{
The Monitoring and Molecular Identification of the Mealybug, Phenacoccus solenopsis Tinsley (Hemiptera: Pseudococcidae) on Okra Plants at Sharkia Governorate
}

\author{
Nabil, H.A. 1, I.M. Ismail ${ }^{2}$, M.M.A. Elashtokhy ${ }^{3}$, M.A.M. Hegab ${ }^{4}$ \\ 1. Plant Protection Research Institute, ARC, Dokki, Giza, Egypt. \\ 2. Department of Microbial Molecular Biology, Agricultural Genetic Engineering \\ Research Institute (AGERI), Agricultural Research Center (ARC), Giza 12619, Egypt. \\ 3. Genetic Department, Faculty of Agriculture, Zagazig University, Egypt. \\ 4. Plant Protection Department, Faculty of Agriculture, Zagazig University, Egypt. \\ *E. Mail: hegabmohamad@gmail.com
}

\section{ARTICLE INFO}

Article History

Received:28/10/2020

Accepted:30/12/2020

Keywords:

Phenacoccus

solenopsis,

molecular

characterization,

occurrence,

okra,

Sharkia

Governorate.

\section{INTRODUCTION}

\section{ABSTRACT}

Mealybugs (Hemiptera: Pseudococcidae) are small piercing-sucking insects that infesting a wide range of crops and vegetables and their species are similar, which makes it difficult for non-specialists to distinguish between them. Samples were collected of infested okra plants from five districts at Sharkia Governorate, Egypt. This study aimed to study the distribution of the cotton mealybug, Phenacoccus solenopsis Tinsley and its associated parasitoid as well as the identification of this species by molecular characterization due to the high degree of morphological similarity between different closely related species of mealybugs. It was found that the Parasitism has a big influence on the occurrence of this insect infestation and this species of mealybug was confirmed by amplified and sequenced DNA loci known to be informative for species identification by provides information of $28 \mathrm{~S}$ ribosomal RNA gene sequence. Consequently, the success of IPM programs against mealybugs depends on the correct definition of this pest through genetic characterization to choose the best control strategies. On the other hand, the difficulty of correctly identifying these species leads to its difficulty in choosing appropriate methods of control, especially biological control where each pest has a specific species of its natural enemy, which controls it biologically.

Okra (Abelmoschus esculentus L.) is one of the major popular vegetables in Egypt. Incidence of mealybug pest, Phenacoccus solenopsis Tinsley on okra has been reported by many authors from different parts of the country while being responsible for considerable yield loss (Abd-Rabou et al., 2010; Ibrahim et al., 2015; Nabil et al., 2015 and Rezk et al., 2019). Sample collections of mealybugs were surveyed from the okra plants at Sharkia Governorate. Dewer et al. (2018) recorded that the Phenacoccus solani Ferris is a new pest in Egypt. Mealybugs feed by piercing leaves and fruits and sucking plant sap from them, these cause direct and indirect damages while feeding and cause malformation for leaves, branches and fruits that lead to decreased the quality and marketing value of plants ( Douglas and Kruger 2008; Meyer et al.,2008; Nakaune et al.,2008; Mahfoudhi et al., 2009; Garcia Morales et al., 2016 and Nabil and Hegab 2019). 
The morphological identification of scale insects can be difficult particularly for non- specialists. On the other hand, the taxonomic identification methods are currently based on keys dealing with different external body structures of adult female species but the use of this method is impossible to distinguish nymphs and males of this pest. The difficulty of correctly identifying these species affected selecting the suitable control strategies, particularly biocontrol. This problem has led to the development of molecular tools used to obtain accurate identification of species of Pseudococcidae using DNA barcoding (Park et al., 2011; Abd-Rabou et al., 2012; Correa et al., 2012 and Pacheco Da Silva et al., 2014). In this study, the authors have focused on the use of DNA markers to distinguish between closely related species of mealybugs for agronomic applications (Cavalieri et al., 2008; Rung et al., 2008 and Saccaggi et al., 2008). This study helps us to further track the spread of this species in the region and provides $28 \mathrm{~s}$ ribosomal RNA gene sequence of its. Therefore, this investigation has contributed to the development of new tools for mealybug characterization, but it remains difficult to evaluate the efficacy of different markers for distinguishing between closely related species of Pseudococcidae.

\section{MATERIALS AND METHODS}

\section{Plant Material:}

\section{Sample Collection:}

Twenty-five samples were surveyed from different five districts; Zagazig, Hihya, Abo-Hammad, MinaElkamh and Abo-Kabier, at Sharkia Governorate, Egypt during 2020 season. Each sample consisted of twenty-five leaves transferred to the laboratory and examined using a stereomicroscope on the same day. The different stages of $P$. solenopsis on both surfaces of the leaves were counted and recorded.

To study the percentage of parasitism of $P$. solenopsis, the insects on each sample were separated into healthy alive insects and mummies of its insect. The percentages of parasitism were recorded. Specimens were conserved in ethanol $(95 \%)$ and stored at $20^{\circ} \mathrm{C}$ for identification and molecular analyses.

DNA Extraction, Amplification And Sequencing:

\section{DNA Preparation and PCR Amplification:}

Genomic DNA was extracted from insect samples using a DNeasy Blood \& Tissue extraction kit (Qiagen, CA, USA) according to the manufacturer's instructions. In order to identify the samples by molecular methods, PCR amplification and sequencing of $28 \mathrm{~S}$ rRNA were carried out.

The primers were used for amplification of the 28S rRNA gene using 28S-D2 primers forward and reverse $F\left(5^{\prime}\right.$ AGAGAGAGTTCAAGAGTACGTG -3') and $\mathrm{R}$ (5'TTGGTCCGTGTTTCAAGACGGG -3') according to Malausa et al., 2011.

DNA amplification was performed in a $50 \mu \mathrm{L}$ volume containing 30ng of DNA template, $250 \mathrm{mM}$ each dNTP, $25 \mathrm{pmol}$ each primer, $2.5 \mathrm{mM} \mathrm{MgCl} 2,10 \mu \mathrm{L}$ of $5 \mathrm{x}$ PCR buffer, 2.5 U Taq polymerase (Promega) and dist. $\mathrm{H}_{2} \mathrm{O}$ to a final volume of $50 \mu \mathrm{L}$. The reactions were performed in an automatic thermal cycler (GeneAmp1 PCR System 9700, Perkin-Elmer) under the following conditions: initial denaturation at $94{ }^{\circ} \mathrm{C}$ for $3 \mathrm{~min} ; 35$ cycles of $94{ }^{\circ} \mathrm{C}$ for $40 \mathrm{~s}, 58{ }^{\circ} \mathrm{C}$ for $50 \mathrm{~s}$, and $72{ }^{\circ} \mathrm{C}$ for $60 \mathrm{~s}$; and a final extension at $72{ }^{\circ} \mathrm{C}$ for $7 \mathrm{~min}$. An aliquot of $10 \mu \mathrm{L}$ PCR products was analyzed on a $1 \%$ agarose gel.

\section{Sequencing and Data Analysis:}

Sequencing analysis was performed on a 300 bp PCR product. The purification of the PCR product was carried out using a high pure PCR purification kit (Qiagen). DNA sequences were determined by the automated DNA sequencing method. The automated DNA sequencing reactions were performed using an ABI PRISM Big Dye 
Terminator Cycle Sequencing Ready Reaction kit (PE Applied Biosystems, USA) in conjunction with ABI PRISM (310 Genetic Analyzer). Alignment of The sequencing data was compared with other rDNA sequences in GenBank using the NCBI Basic Local alignment search tools (BLAST) (http://www.ncbi.nlm.nih.gov/BLAST).

The top five homologous hits were selected for neighbor-joining and multiple alignments with Clustal W methods. The alignment results were used to construct a Phylogenetic tree using DNAStar, version 7.1, software.

\section{RESULTS}

Occurrence of Phenacoccus solenopsis Tinsley and its Parasitoid:

Data in Table (1) give some remarks on the distribution of mealybug species inhabiting okra crops in different localities ( Mina-Elkam, Zagazig, hihya, Abo-Hammad and Abo-Kabier districts) at Sharkia governorate, Egypt. The Parasitism has a high effect on the occurrence of the infestation with mealybug, whereas, the highest incidence of infestation arranged in descending in the Zagazig, followed by Mina al-Qamh then Abo- Hammad then Abo-Kabier and Hihya districts, respectively. The highest numbers of adult females were recorded in Mina-Elkamh distract and represented by 471 individuals, while the highest numbers of nymphs occurred in Zagazig distract with values of 3488 individuals. On the other hand, the lowest numbers of adult females and nymphs occurred in hihya distract and were represented by 21 and 399 individuals, respectively.

Table 1: Occurrence of Phenacoccus solenopsis Tinsley infesting okra plant at Sharkia Governorate during the 2020 season.

\begin{tabular}{|l|c|c|c|c|}
\hline \multirow{2}{*}{ Distracts } & \multicolumn{3}{|c|}{ Number of insects } & $\begin{array}{c}\text { Percentage of } \\
\text { parasitism } \\
\text { (\%) }\end{array}$ \\
\cline { 2 - 4 } & Females & Nymphs & Total alive stages & 3.809 \\
\hline Mina-Elkamh & 471 & 2128 & 2599 & 1.022 \\
\hline Zagazig & 36 & 3488 & 3524 & 9.234 \\
\hline Abo-Hammad & 93 & 1044 & 1137 & 33.571 \\
\hline Hihya & 21 & 399 & 420 & 3.087 \\
\hline Abo-Kabeer & 336 & 2028 & 2364 & \\
\hline
\end{tabular}

It was found that the increase in population of tested insect was related to the decreased percentage of parasitism. Whereas, the percentage of parasitism reached to maximum in Hihya district together with the lowest numbers of alive stages. While, the lowest percentage of parasitism was recorded in Zagazig district with the minimum numbers of insect stages. Nabil and Hegab (2019) reported that the population density of tested insect was indirectly correlated with the parasitism .

\section{S Ribosomal RNA Gene Analysis:}

PCR products of approximately $300 \mathrm{bp}$ amplified with the 28S-D2 F and $\mathrm{R}$ primers and corresponding to the $28 \mathrm{~S}$ ribosomal RNA gene were obtained from all strains (five selected strains) (Fig.1). After purification of PCR products and sequencing, the results of the BLAST-n alignment showed that all five sequences were associated with high levels of sequence similarity $(98-100 \%)$ with the 28S ribosomal RNA gene sequences for the species, $P$. solenopsis. So, the samples collected were diagnosed as similar to this species. 


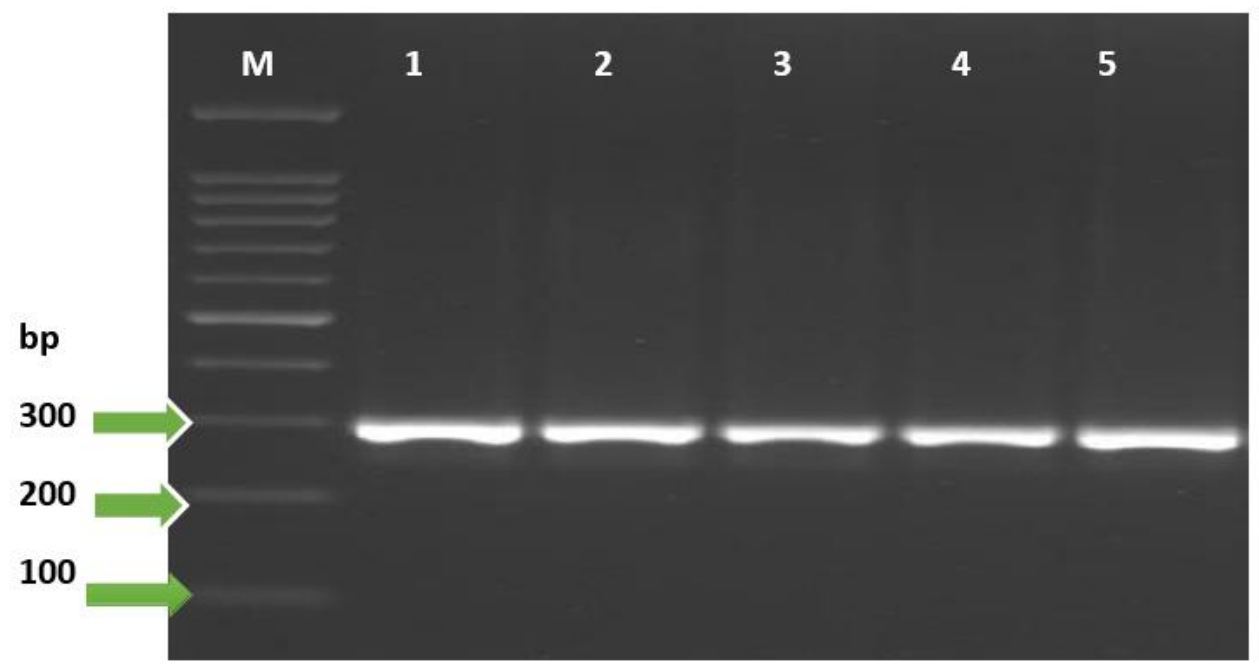

Fig.1: Amplification of 28S r RNA gene from of five strains Sh1, Sh2, Sh3, Sh4, and Sh5. M: 100 bp DNA ladd.

\section{Phenacoccus_solenopsis_Sh1}

TTTCTCTTTGGGTACGGAAGAGCC CGTGATCCGGGCGGCAGAATTCAG AGACGATGGCGGCAACGTTGTCGG TTCGATATTTCTGTCGCCGGCACG GACGTCGCGACCCGTTTGGTGTCG GTCTCAGGAGACGCGTTTCACGTT CGTCGACGCGTCGTCTGCCTCGGT AGGCGCGCGTTGCGAGTACGCGTT CGTGTTCCGGCCGACTCGCCAGAC GGTAGGTTAATGGTGGCCGCGGCG GTCGTTCGCTTCGCGGCGATCAGC GCCGTCCGCGGTGCCGGTTTGCGA CGAATCTTCGGGCCTCTTTCCGAC CCGTCTTGAAACACCGGACCAA

Phenacoccus_solenopsis_Sh2 TTTTCGCGCCGTGATCCGGGCGGC AGATTAGAGACGATGGCGGCACGT TGTCGGTCGATATTTCTGTCGCCG GCACGGACGTCGCGATCGTTTGGT GTCGGTCTCAGGAGACGCGTTTCA CGTTCGTCGACGCGTCGTCTGCCT CGGTAGGCGCGCGTTGCGAGTACG CGTTCGTGTTCCGGCCGACTCGCC AGACGGTAGGTTAATGGTGGCCGC GGCGGTCGTTCGCTTCGCGGCGAT CAGCGCCGTCCGCGGTGCCGGTTT GCGACGAATCTTCGGGCCTCTTTC CGACCCGTCTTG

ACAACGGGACCAA

Phenacoccus_solenopsis_Sh3
CCCGGATTCAGGTACGGACAGAGC CCGTGAATCCGGGCGGCAGAATTC AGAGACGATGGCGGCAACGTTGTC GGTTCGATATTTCTGTCGCCGGCA CGGACGTCGCGACCCGTTTGGTGT CGGTCTCAGGAGACGCGTTTCACG TTCGTCGACGCGTCGTCTGCCTCG GTAGGCGCGCGTTGCGAGTACGCG TTCGTGTTCCGGCCGACTCGCCAG ACGGTAGGTTAATGGTGGCCGCGG CGGTCGTTCGCTTCGCGGCGATCA GCGCCGTCCGCGGTGCCGGTTTGC GACGAATCTTCGGGCCTCTTTCCG ACCCGTCTTGAAACACGGACCAA

Phenacoccus_solenopsis_Sh4 CCGGATTCGGGGTACGGACAGAGC CCGTGATCCGGGCGGCAGAATTCA GAGACGATGGCGGCAACGTTGTCG GTTCGATATTTCTGTCGCCGGCAC GGACGTCGCGACCCGTTTGGTGTC GGTCTCAGGAGACGCGTTTCACGT TCGTCGACGCGTCGTCTGCCTCGG TAGGCGCGCGTTGCGAGTACGCGT TCGTGTTCCGGCCGACTCGCCAGA CGGTAGGTTAATGGTGGCCGCGGC GGTCGTTCGCTTCGCGGCGATCAG CGCCGTCCGCGGTGCCGGTTTGCG ACGAATCTTCGGGCCTCTTTCCGA CCCGTCTTGAAACACGGACCAA Phenacoccus_solenopsis_Sh5 CCCGGATCAGGTACGGAAGAGCCC 
GTGATCCGGGCGGCAGAATTCAGA GACGATGGCGGCAACGTTGTCGGT TCGATATTTCTGTCGCCGGCACGG ACGTCGCGACCCGTTTGGTGTCGG TCTCAGGAGACGCGTTTCACGTTC GTCGACGCGTCGTCTGCCTCGGTA GGCGCGCGTTGCGAGTACGCGTTC GTGTTCCGGCCGACTCGCCAGACG GTAGGTTAATGGTGGCCGCGGCGG TCGTTCGCTTCGCGGCGATCAGCG CCGTCCGCGGTGCCGGTTTGCGAC GAATCTTCGGGCCTCTTTCCGACC CGTCTTGAAACACCGGACCAA

The sequences have been submitted to GenBank database and accession numbers were obtained (MN887775, MN887776, MN887777, MN887778 and MN887779). Megaalignment was applied among the five nucleotide sequences that were found to be $\quad P$. solenopsis in our study and the top five homologous hits of $28 \mathrm{~S}$ rRNA from the NCBI databank. Additional five sequences of $28 \mathrm{~S}$ rRNA of $P$. solani were used to extend the genetic variation. The data in the phylogenetic tree showed that the sequences can be divided into two major branches. One major branch has comprised all the $P$. solenopsis including those of the current study. While the other major branch has comprised the sequences of $P$. solani. The results proved that sequences of the current study are truly more related to $P$. solenopsis than $P$. solani. Also, the sequences were highly related with 98.9 $\%$ of similarity to each other and a maximum deviation 1.1\% (Fig.2).

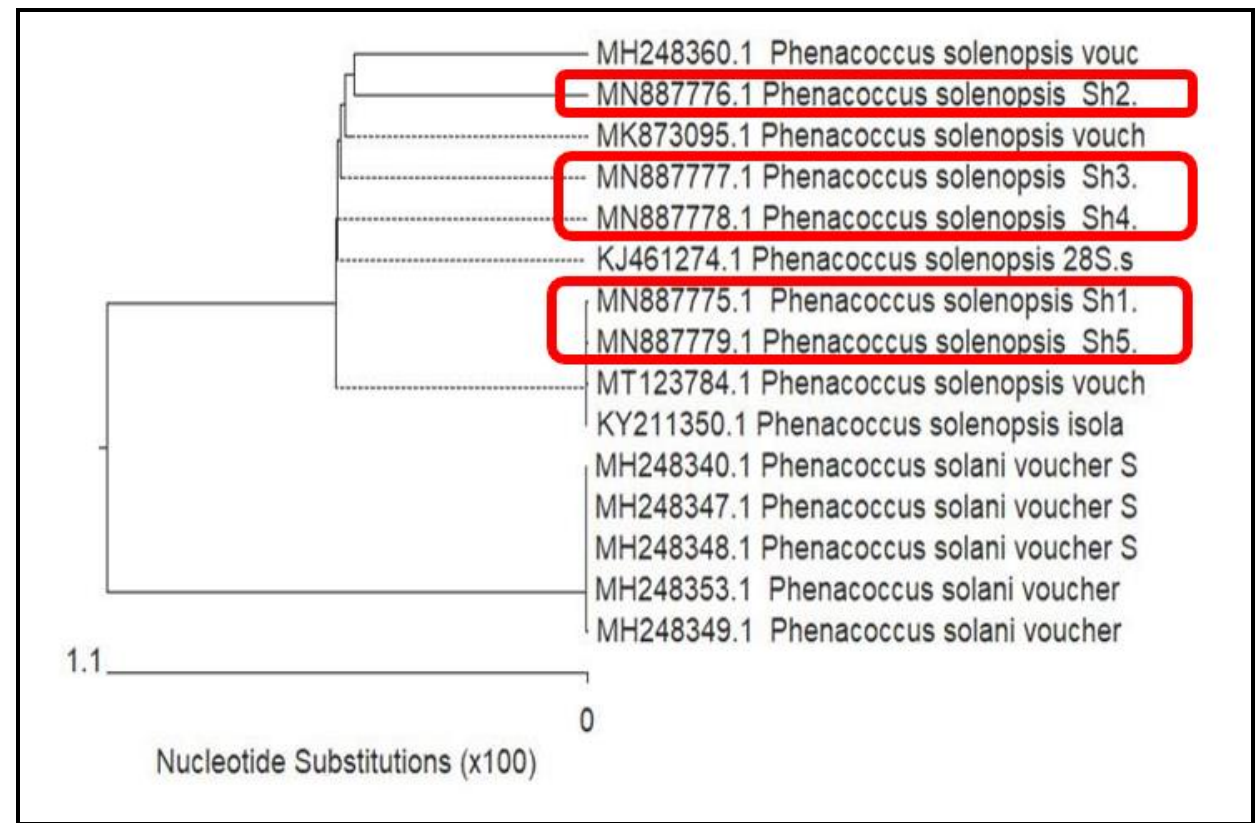

Fig. 2. Phylogenic tree based on the 28 rDNA gene sequences and relationship among the five accession numbers of identified strains (red squared) and the top homologous on the NCBI data base.

In conclusion, the aim of the study is to identify the sequencing of $28 \mathrm{~S}$ rRNA of the cotton mealybug, $P$. solenopsis, due to the presence of other morphologically similar genera with a high percentage of this species that was discovered in Rashid Governorate where, the solanum mealybug, $P$. solani, is similar in appearance to the cotton mealybug $P$. solenopsis, and there is some evidence to suggest they might represent environmentally induced forms of the same species according to Hodgson et al. (2008) pointed out in their detailed study of 
morphological variation that these three species might be environmentally induced variants of a single species. In addition to the correct identifying of the mealybugs is important for succeeding in the controlling, as biological control depends mainly on biological enemies or pheromone traps that are specific to certain species. (Dewer et al., 2012 and Mani and Shivaraju 2016). Therefore, the aim of this research reported that the populations of insect were indirectly related with the percentage of parasitism and confirmed that the dominant species at Sharkia Governorate was $P$. solenopsis. In addition, the PCR was useful for the rapid and cost-efficient identification of this species.

\section{REFERENCES}

Abd-Rabou, S., J.F. Germain and T. Malausa (2010). Phenacoccus parvus Morrison et $P$. solenopsis Tinsley, deux Cochenilles nouvelles pour l'Egypte (Hemiptera: Pseudococcidae). Bulletin de la Société Entomologique de France, 115(4): 509- 510.

Burland, T.G. DNASTAR's Lasergene sequence analysis software. Methods in Molecular Biological, 2000;132:71-91

Cavalieri, V., G. Mazzeo, G.T. Garzia, E. Buonocore, A. Russo (2008). Identification of Planococcus ficus and Planococcus citri (Hemiptera: Pseudococcidae) by PCR-RFLP of coigene. Zootaxa, 1816, 65-68.

Correa, M.C.G., J-F. Germain, T. Malausa and T. Zaviezo (2012). Molecular and morphological characterization of mealybugs (Hemiptera: Pseudococcidae) from Chilean vineyards. Bulletin of Entomological Research , 102: 524-530.

Dewer, Y., S. Abdel-Razak and A. Barakat (2012). Comparative efficacy of some insecticides against purple scale insect, Lepidosaphes beckii (Hemiptera: Coccoidea) and its parasitoid in citrus orchard in
Egypt. Egyptian Academic Journal of Biological Sciences,A.Entomology, Vol. 5, 121-127.

Dewer,Y., R. S. Abdel-Fattah and S. A. Schneider (2018). Molecular and morphological identification of the mealybug, Phenacoccus solani Ferris (Hemiptera:

Pseudococcidae): first report in Egypt. Bulletin OEPP/EPPO, 48(1), 155-159.

Douglas, N. and K. Kruger (2008). Transmission efficiency of grapevine leafroll-associated virus 3 (glrav-3) by the mealybugs Planococcus ficus and Pseudococcus longispinus (Hemiptera : Pseudococcidae). European Journal of Pathology, 122, 207-212.

Garcia Morales, M., B.D. Denno, D.R. Miller, G.L. Miller, Y. Ben-Dov and N.B. Hardy (2016). ScaleNet: A literature-based model of scale insect biology and systematics. Database, 2016, bav118.

Hodgson, C.J., G. Abbas, M.J. Arif, S. Saeed and H. Karar (2008). Phenacoccus solenopsis Tinsley (Sternorrhyncha: Coccoidea: Pseudococcidae), a new invasive species attacking cotton in Pakistan and India, with a discussion on seasonal morphological variation. Zootaxa, 1913: 1-35.

Ibrahim, S.S., F.A. Moharum and N.M. Abd El-Ghany (2015). The cotton mealybug Phenacoccus solenopsis Tinsley

(Hemiptera: Pseudococcidae) as a new insect pest on tomato plants in Egypt. Journal of Plant Protection Research, 55 (1): 48-51.

Mahfoudhi, N., M. Digiaro and $M$. Dhouibi (2009). Transmission of grapevine leafroll viruses by Planococcus ficus (Hemiptera: Pseudococcidae) and Ceroplastes rusci (Hemiptera: Coccidae) .Plant 
Disease, 93, 999-1002.

Malausa, T., A. Fenis, S. Warot, J.F. Germain, N. Ris, E. Prado, M. Botton, F. Vanlerberghe-Masutti, R. Sforza, C. Cruaud, A. Couloux and P. Kreiter (2011). DNA markers to disentangle complexes of cryptic taxa in mealybugs (Hemiptera: Pseudococcidae). Journal of Applied Entomology, $135,142-155$.

Mani, M. and C. Shivaraju (2016). Mealybugs and their management inagricultural and horticultural crops. Part I: Biology (Eds. Mani M \&Shivaraju C), pp. 87-106. Springer, India.

Meyer, J.B., G.G.F. Kasdorf, L.H. Nel and G. Pietersen (2008). Transmission of activated-episomal banana streak ol(badna)virus (bsolv) to cv. Williams banana(musa sp.) by three mealybug species. Plant Disease, 92,1158-1163.

Nabil, H. A. and M.A.M. Hegab (2019). Impact of Some Weather Factors on the Population Density of Phenacoccus solenopsis Tinsley and its Natural Enemies. Egyptian Academic Journal of Biological Sciences ,A.Entomology, 12(2): 99108.

Nabil, H.A., A.SH. Hassan, and SH.A.A. Ismail (2015). Registration of the cotton mealybug, Phenacoccus solenopsis Tinsley (Hemiptera: Sternorrhyncha: Coccoidea: Pseudococcidae) for the first time on four economical crops in Egypt. Zagazig Journal of Agriculture Research, 42(6): 1555-1560.

Nakaune, R., S. Toda, M. Mochizuki, A. Nakano Rung, S.J. Scheffer, G. Evans and D. Miller (2008). Molecular identification of two closely related species of mealy- bugs of the genus Planococcus (Homoptera: Pseudococcidae). Annals Entomological Society America , 101, 525-532.

Pacheco da Silva, V.C., A. Bertin, A. Blin, J-F. Germain, D. Bernardi, G. Rignol, M. Botton and T. Malausa (2014). Molecular and Morphological Identification of Mealybug Species (Hemiptera: Pseudococcidae) in Brazilian Vineyards. Plos One, 9(7): e103267.

Park, D.S., S.J. Suh, P.D. Hebert, O.h. HW and K.J. Hong (2011). DNA barcodes for two scale insect families, mealybugs (Hemiptera: Pseudococcidae) and armored scales (Hemiptera: Diaspididae). Bulletin of Entomological Research, 101, 429-434.

Rezk, M., A.T. Hassan, M.F. El-Deeb, N. Shaarawy and Y. Dewer (2019). The impact of insecticides on the cotton mealybug, Phenacoccus solenopsis (Tinsley): Efficacy on potato, a new record of host plant in Egypt. Journal of Agriculture Research, 59(1): 50-59.

Rung, A., S.J. Scheffer, G. Evans and D. Miller (2008). Molecular identification of two closely related species of mealy-bugs of the genus Planococcus (Homoptera: Pseudococcidae). Annals Entomological Society America, 101, 525-532.

Saccaggi, D.L., K. Kruger and G. Pietersen (2008). A multiplex PCR assay for the simultaneous identification of three mealybug species (Hemiptera: Pseudococcidae). Bulletin of Entomological Research , 98, 2733. 


\section{ARABIC SUMMARY}

\section{Phenacoccus solenopsis Tinsley الرصد والتعريف الجزيئى للبق الدقيقي}

(Hemiptera: Pseudococcidae )

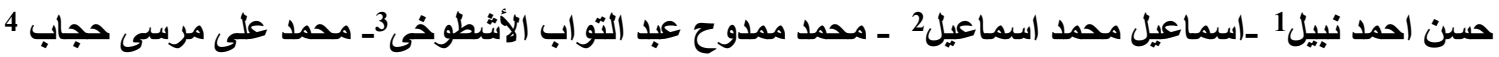

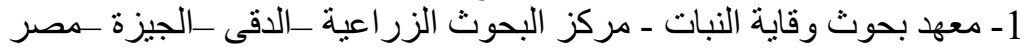

2- قسم البيولوجيا الجزئية الميكروبية ـ معهد بحوث الهندسه الور اثيه الزر اعبه ـ مركز البحوث الزية الزية اعية ـ الاقى ـ

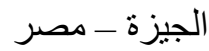

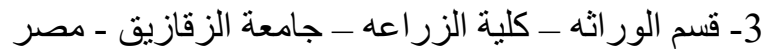

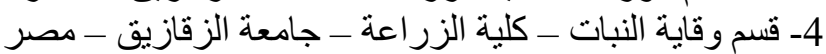

البق الدقيقي (Hemiptera: Pseudococcidae) عبارة عن حشر ات ثاقبة ماصه وصغيرة الحجم وتصيب

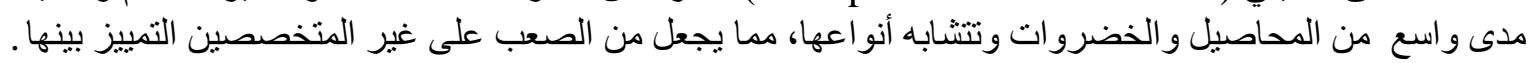

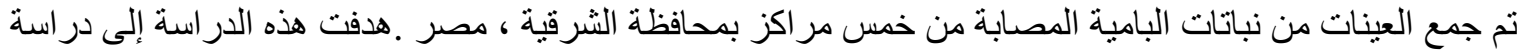

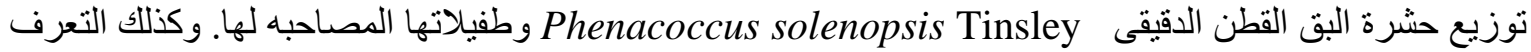

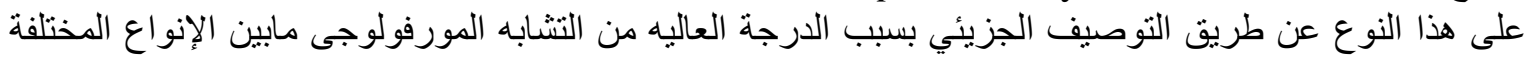

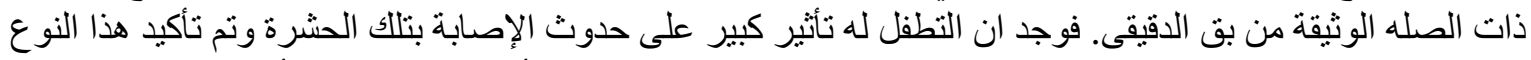

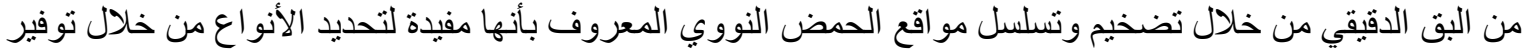

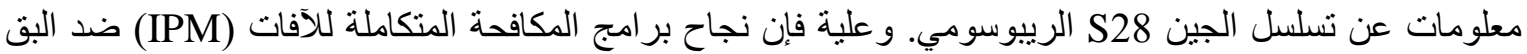

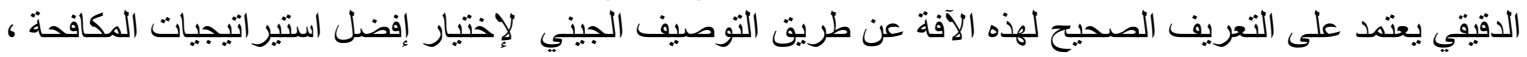

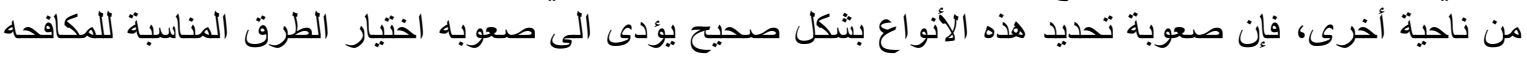

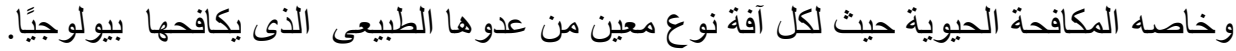

